\title{
Flower nectar trichome structure of carnivorous plants from the genus butterworts Pinguicula L. (Lentibulariaceae)
}

\author{
Krzysztof Lustofin ${ }^{1} \cdot$ Piotr Świątek ${ }^{2} \cdot$ Vitor F. O. Miranda ${ }^{3} \cdot$ Bartosz J. Płachno $^{1}$ (D)
}

Received: 23 June 2019 / Accepted: 7 August 2019 / Published online: 19 August 2019

(C) The Author(s) 2019

\begin{abstract}
Pinguicula (Lentibulariaceae) is a genus comprising around 96 species of herbaceous, carnivorous plants, which are extremely diverse in flower size, colour and spur length and structure as well as pollination strategy. In Pinguicula, nectar is formed in the flower spur; however, there is a gap in the knowledge about the nectary trichome structure in this genus. Our aim was to compare the nectary trichome structure of various Pinguicula species in order to determine whether there are any differences among the species in this genus. The taxa that were sampled were Pinguicula moctezumae, P. moranensis, P. rectifolia, P. emarginata and P. esseriana. We used light microscopy, histochemistry, scanning and transmission electron microscopy to address those aims. We show a conservative nectary trichome structure and spur anatomy in various Mexican Pinguicula species. The gross structural similarities between the examined species were the spur anatomy, the occurrence of papillae, the architecture of the nectary trichomes and the ultrastructure characters of the trichome cells. However, there were some differences in the spur length, the size of spur trichomes, the occurrence of starch grains in the spur parenchyma and the occurrence of cell wall ingrowths in the terminal cells of the nectary trichomes. Similar nectary capitate trichomes, as are described here, were recorded in the spurs of species from other Lentibulariaceae genera. There are many ultrastructural similarities between the cells of nectary trichomes in Pinguicula and Utricularia.
\end{abstract}

Keywords Butterworts · Carnivorous plant · Floral micromorphology $\cdot$ Lentibulariaceae $\cdot$ Nectary structure $\cdot$ Pinguicula $\cdot$ Spur . Trichomes

\section{Introduction}

Lentibulariaceae L. is a monophyletic family within the Lamiales (APG IV 2016; Schäferhoff et al. 2010) and contains

Handling Editor: Peter Nick

Electronic supplementary material The online version of this article (https://doi.org/10.1007/s00709-019-01433-8) contains supplementary material, which is available to authorized users.

Bartosz J. Płachno

bartosz.plachno@uj.edu.pl

1 Department of Plant Cytology and Embryology, Institute of Botany, Faculty of Biology, Jagiellonian University in Kraków, 9 Gronostajowa St, 30-387 Kraków, Poland

2 Department of Animal Histology and Embryology, University of Silesia in Katowice, 9 Bankowa St, 40-007 Katowice, Poland

3 Departamento de Biologia Aplicada à Agropecuária, Universidade Estadual Paulista (Unesp), Faculdade de Ciências Agrárias e Veterinárias, Jaboticabal, São Paulo, Brazil about 360 species. This family consists of three genera of carnivorous plants: Pinguicula L., Genlisea A. St.-Hil. and Utricularia L. (e.g. Juniper et al. 1989; Jobson et al. 2003; Müller et al. 2004; Fleischmann and Roccia 2018). The family Lentibulariaceae probably originated about 42 million years ago (Ibarra-Laclette et al. 2013; Silva et al. 2018). Most probably, the genus Pinguicula originated in South America. It is the second largest genus of this family and contains about 96 currently recognised species. Pinguicula species occur on all of the continents except for Australia, with its centre of diversity in Central America (Casper 1966; Beck et al. 2008; Roccia et al. 2016; Fleischmann and Roccia 2018).

Although all Lentibulariaceae genera contain plants that are carnivorous herbs, they use the different strategies for capturing their prey. The Genlisea species have subterranean eel (lobster-pot) traps for trapping small water/soil invertebrates, while the Utricularia species form suction bladders (e.g. Lloyd 1942; Juniper et al. 1989; Reut 1993; Płachno et al. 2007, 2019a; Poppinga et al. 2016). Pinguicula species are active 'flypapers' that have a basal rosette of slightly modified 
leaves for trapping small invertebrates. Pinguicula leaves have two types of epidermal glandular trichomes (stalked and sessile) on their upper surfaces. Stalked trichomes carry mucilaginous droplets for trapping prey, which the sessile trichomes produce digestive enzymes and absorb the nutrients from digested prey (e.g. Heslop-Harrison 1970; HeslopHarrison and Heslop-Harrison 1980; Legendre 2000; Adlassnig et al. 2010). Some species, e.g. P. gigantea and $P$. longifolia, also have mucilage trichomes on their lower leaf surface (Fleischmann and Roccia 2018). Their natural prey is mainly small flying Diptera (Nematocera) and other insects (Coleoptera, Thysanoptera, Lepidoptera) as well as springtails (Collembola), mites, spiders and gastropods (e.g. Karlsson et al. 1987; Zamora 1990, 1999; Heslop-Harrison 2004; Adler and Malmqvist 2004; Alcalá and Domínguez 2003, 2005; Darnowski et al. 2018).

Members of Lentibulariaceae have zygomorphic flowers that have a sympetalous corolla that is bilobed. The upper lip is formed by two and the lower lip by three fused petals. In all three genera, there are flower spurs, which are tubular outgrowths of the perianth organs and contain nectar for their pollinators (Casper 1966; Taylor 1989; Fischer et al. 2004; Fleischmann et al. 2010; Aranguren et al. 2018; Płachno et al. 2017, 2018, 2019b, c). In Pinguicula, the corolla is throat-like and its shape is either distinctly zygomorphic (Fig. 1a-1) with the lower lip spreading widely from the upper lip or nearly isolobous and radial (Fleischmann and Roccia 2018). The flowers vary in their sizes, colours (from red, violet, pink, blue to white) and spur size and shape (Fig. 1a-1; see Casper 1966; Roccia et al. 2016; Lampard et al. 2016).

Pinguicula species are extremely diverse in their pollination strategies. Schnell (1976) proposed that the tubular Pinguicula flowers are pollinated by long-tongued insects. Hymenoptera (bumblebees, carpenter bees, honeybees and other smaller bees) are the primary flower visitors in the Pinguicula species in the south-eastern USA: Pinguicula ionantha, P. lutea and P. planifolia (Molano-Flores et al. 2018). The flowers of the Mediterranean $P$. vallisneriifolia have specialised floral traits (large, spurred flowers, contrasting colours, floral guides and the presence of nectar), which suggest a bee type of flower. Although $P$. vallisneriifolia flowers are visited by hymenoptera, thrips (Thripsmeridionalis) and small beetles (Eusphalerumscribae) are the primary pollen vectors for this species (Zamora 1999). Thus, despite their specialised floral traits for bee pollination syndrome, the main pollinators belong to other groups (Zamora 1999). According to Heslop-Harrison (2004), the flowers of P. vulgaris are primarily bee pollinated. The flowers of $P$. alpina are adapted for insect pollination mainly by flies but also by bees (Molau 1993; Heslop-Harrison 2004). In Gotland, $P$. alpina flowers were visited by both flies and bees:
Melanostomascalare, Platycheirusalbimanus, Lasioglossumfratellum, Lasioglossumalbipes, Dasysyrphus and members of Empididae and Anthomyiidae (Nordin 2015). According to this author, short-tongued insects can also pollinate this species because both the throat and spur in P. alpina flowers are wide, which enables penetration. The Mexican Pinguicula species (P. moranensis), which produce large, coloured, hercogamous flowers that have long spurs, are pollinated by Lepidoptera (Zamudio 2001; Villegas and Alcalá 2018, see Fig. 5 in Villegas and Alcalá 2018, which presents a beautiful "Schematic representation of pollination in Pinguicula moranensis"). According to Abrahamczyk et al. (2017), Pinguicula macrophylla and P. moctezumaeare are also pollinated by Lepidoptera. Pinguicula hemiepiphytica and the related Pinguicula laueana have purple-red or red flowers that have long spurs and are visited by hummingbirds and, most probably, are pollinated by them (Lampard et al. 2016); however, this should be verified because no Pinguicula pollen grains have been observed on the bodies of hummingbirds.

Only a few species have been studied to determine the occurrence of nectar in Pinguicula flowers. Zamora (1999) noted that $P$. vallisneriifolia only produces traces of nectar. Abrahamczyk et al. (2017) showed that the nectar sugar composition varies in the species that are pollinated by different groups of insects, e.g. species that are pollinated by butterflies ( $P$. macrophylla and $P$. moctezumae) had fructose-dominated nectar, while species that are classified as being pollinated by bees and wasps had sucrose-dominated nectar ( $P$. gigantea) or hexose-dominated nectar (P. leptoceras). P. alpina, which was classified by Abrahamczyk et al. (2017) as flypollinated species, also had sucrose-dominated nectar. However, this species is also pollinated by bees (Molau 1993).

In Utricularia, the spur is treated as a nectary and nectar is produced by small glandular trichomes (Płachno et al. 2017, $2018,2019 b, c)$. The ultrastructure of these trichomes was analysed by Płachno et al. (2017, 2019c). Moreover, the small spur trichomes in Genlisea also produce nectar (Fleischmann 2012; Aranguren et al. 2018). However, it is important to note that there is a gap in our knowledge about the nectary trichome structure in Pinguicula. Such data will be very useful in the future in order to create an ancestral state reconstruction and phylogenetic hypothesis of the pollination syndrome in Lentibulariaceae. Therefore, our aim was to compare the nectary trichome structure of various Pinguicula species in order to determine whether there are any differences among species in the genus. In case of P. moranensis, we used a typical flowered plant as well as the white-flowered form to determine whether there are any differences between these forms. 


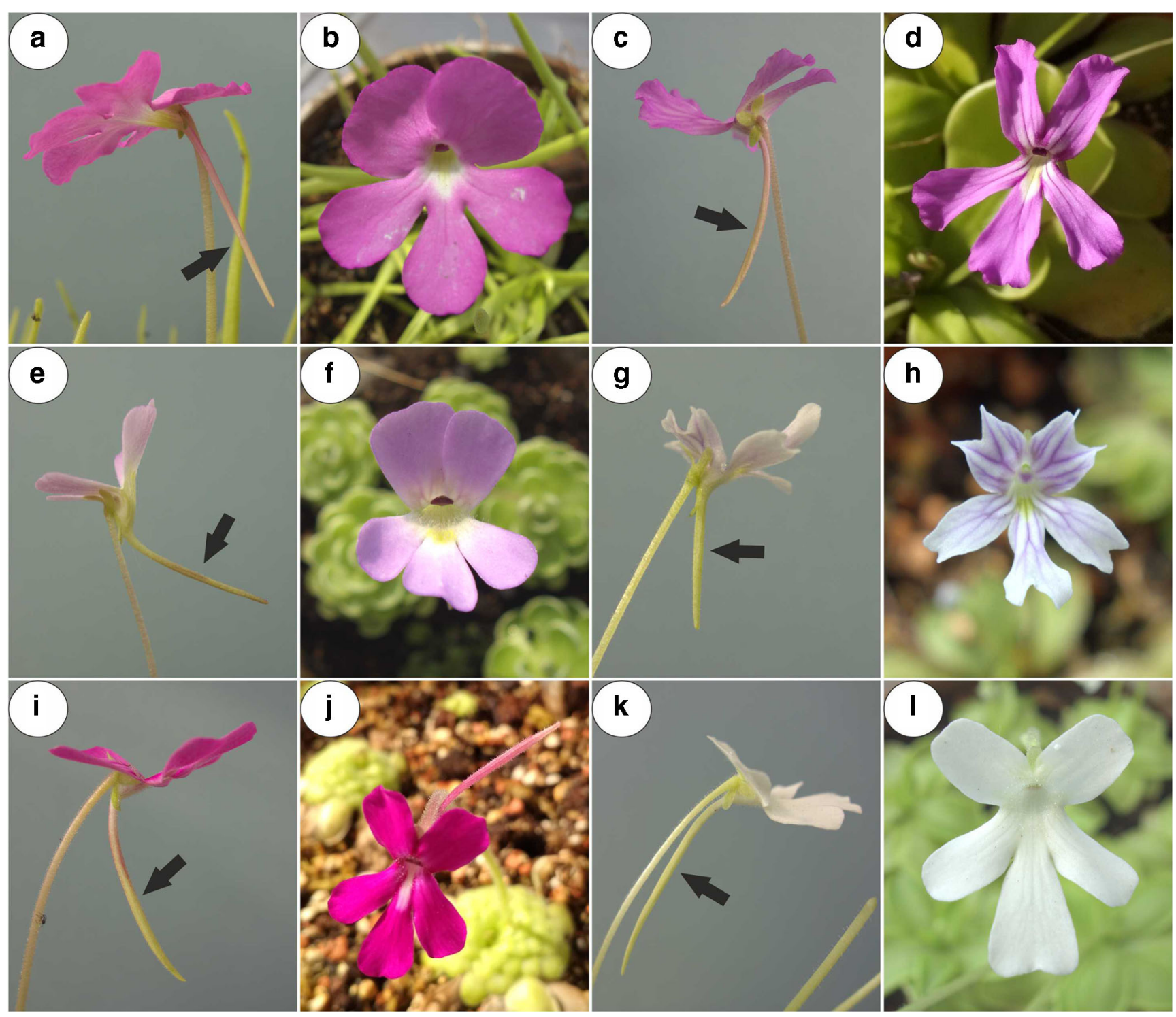

Fig. 1 General floral morphology of the examined Pinguicula species; note the presence of spurs (arrow). a, b P. moctezumae. c, d P. rectifolia. e, f P. esseriana. g, h P. emarginata. i, I P. moranensis

\section{Material and methods}

\section{Plant material}

The plant material (Pinguicula moctezumae Zamudio \& R. Z. Ortega, P. moranensis H. B. K., P. rectifolia Speta \& Fuchs, P. emarginata Zamudio Ruiz \& Rzedowski and $P$. esseriana B. Kirchner; Fig. 1a-1) was bought from the Best Carnivorous Plants Store (KamilPásek, Ostrava, Czech Republic). The plants were later cultivated in the Botanical Garden of the Jagiellonian University in Kraków. For each species, minimum ten flowers (at middle stage of the anthesis) from ten individual plants were collected and studied. All studied flowers were at the same, comparable stage. The length of the spurs of investigated species was Pinguicula moctezumae (25) 28-35 (38) mm; P. moranensis (18) 25-35 (44) mm;
P. rectifolia about $30 \mathrm{~mm}$; $P$. emarginata about $7 \mathrm{~mm}$ and P. esseriana (10) 15-20 (30) mm (Roccia et al. 2016; http:// www.pinguicula.org/pages/pages_principales/content.html).

\section{Methods}

The flower spurs were examined using light microscopy (LM), scanning electron microscopy (SEM) and transmission electron microscopy (TEM) as follows. Small fragments of the apical part of the spurs were fixed in a mixture of $2.5 \%$ or $5 \%$ glutaraldehyde with $2.5 \%$ formaldehyde in a $0.05-\mathrm{M}$ cacodylate buffer (Sigma; $\mathrm{pH}$ 7.2) overnight or for several days, washed three times in a 0.1-M sodium cacodylate buffer and post-fixed in a $1 \%$ osmium tetroxide solution at room temperature for $1.5 \mathrm{~h}$. Dehydration using a graded ethanol 
Table 1 Measurements [average trichome length and head diameter $(\mu \mathrm{m} \pm \mathrm{SD})$ ] of the nectary Pinguicula trichomes $(n=20$ for each species)

\begin{tabular}{llllrr}
\hline Species & P. moctezumae & P. esseriana & P. emarginata & P. moranensis & P. rectifolia \\
\hline Trichome length $(\mu \mathrm{m})$ & $34.41 \pm 3.94$ & $45.36 \pm 3.70$ & $32.74 \pm 3.14$ & $42.41 \pm 6.22$ & $32.49 \pm 2.31$ \\
Head diameter $(\mu \mathrm{m})$ & $26.96 \pm 1.83$ & $32.50 \pm 1.74$ & $22.42 \pm 1.84$ & $31.20 \pm 2.74$ & $24.84 \pm 1.49$ \\
\hline
\end{tabular}

series, infiltration and embedding using an epoxy embedding medium kit (Fluka) followed. After polymerisation at $60{ }^{\circ} \mathrm{C}$, sections for the TEM were cut at $70 \mathrm{~nm}$ using a Leica Ultracut UCT ultramicrotome, stained with uranyl acetate and lead citrate (Reynolds 1963) and examined using a Hitachi H500 transmission electron microscope (Hitachi, Tokyo, Japan), which is housed in the University of Silesia in Katowice, at an accelerating voltage of $75 \mathrm{kV}$. The semi-thin sections $(0.9-$ $1.0 \mu \mathrm{m}$ thick) that were prepared for the LM were stained with aqueous methylene blue/azure II (MB/AII) for 1-2 min (Humphrey and Pittman 1974) and examined using an
Olympus BX60 light microscope for the general histology. The periodic acid-Schiff (PAS) reaction for the LM (semithin sections) was also used to reveal the presence of insoluble polysaccharides and Sudan Black B was used to detect the presence of lipids and cuticle material (Jensen 1962).

Additionally, material that was embedded in Technovit 7100 (Kulzer, Germany) was also observed. The material was fixed in a mixture of $2.5 \%$ or $5 \%$ glutaraldehyde with $2.5 \%$ formaldehyde in a $0.05-\mathrm{M}$ cacodylate buffer (Sigma; $\mathrm{pH}$ 7.2) overnight, washed three times in a 0.1-M sodium cacodylate buffer, dehydrated in a graded ethanol series for
Fig. 2 General anatomy of the examined Pinguicula spurs; Part of the sections through the spurs showing the inner epidermis (ie), external epidermis (ee), parenchyma $(\mathrm{P})$, vascular bundles $(\mathrm{Vb})$, outer glandular trichome (star) and nectary trichomes (arrow). a, b P. moctezumae; scale bar respectively $=100 \mu \mathrm{m}$ and $50 \mu \mathrm{m}$. c $P$. rectifolia; scale bar $=$ $50 \mu \mathrm{m}$. d $P$. esseriana; scale bar $=$ $50 \mu \mathrm{m}$. e $P$. emarginata; scale bar $=50 \mu \mathrm{m}$. f $P$. moranensis; scale bar $=50 \mu \mathrm{m}$

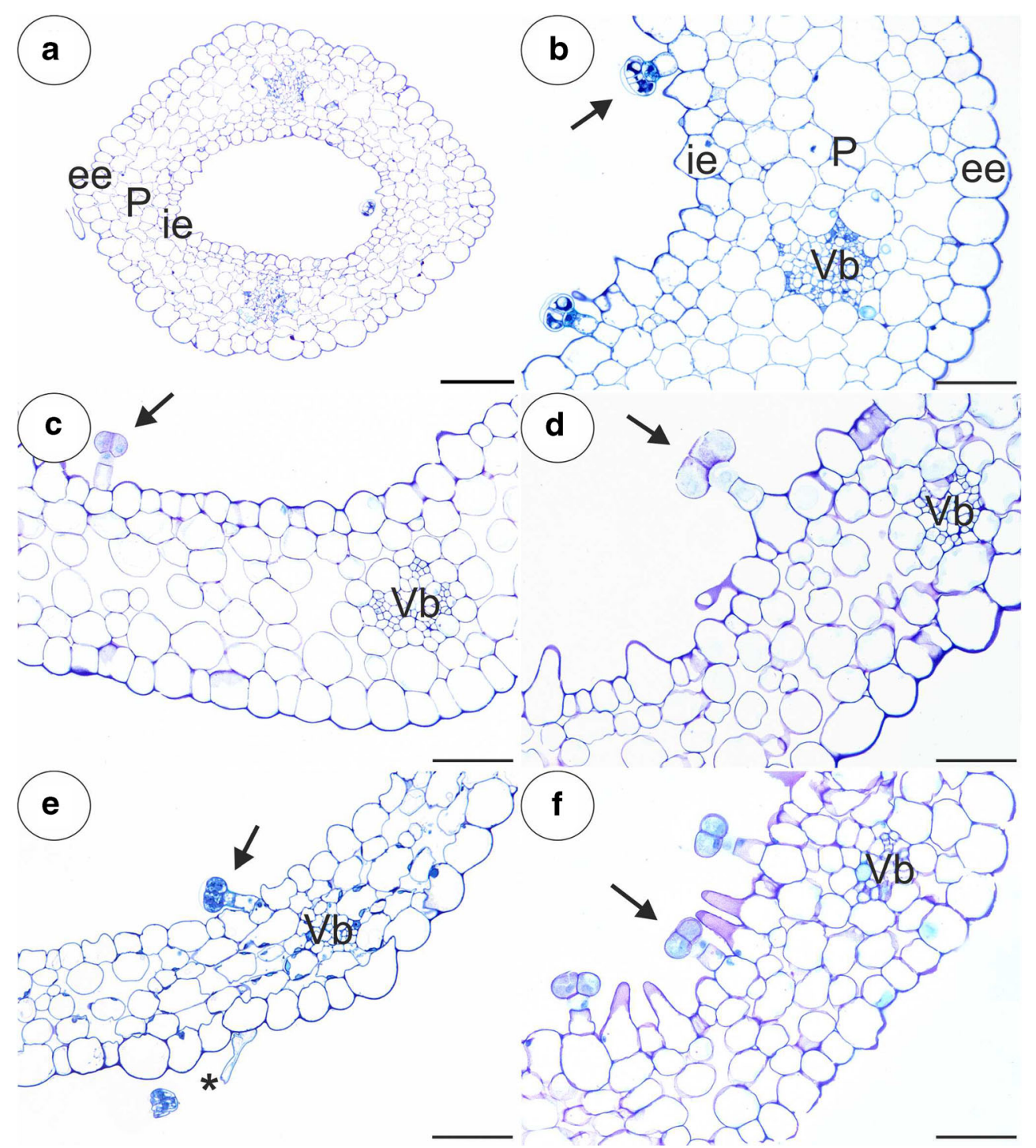


Fig. 3 PAS reaction and Lugol's staining of the examined Pinguicula spurs; note the presence of starch grains (arrow) around the vascular bundle (star), which contains the xylem $(\mathrm{X})$ and phloem (Ph). a P. moctezumae, scale bar $=50 \mu \mathrm{m}$. b P. moranensis, scale bar $=10 \mu \mathrm{m}$. c $P$. moctezumae, scale bar $=$ $100 \mu \mathrm{m}$. d $P$. rectifolia, scale bar $=100 \mu \mathrm{m}$

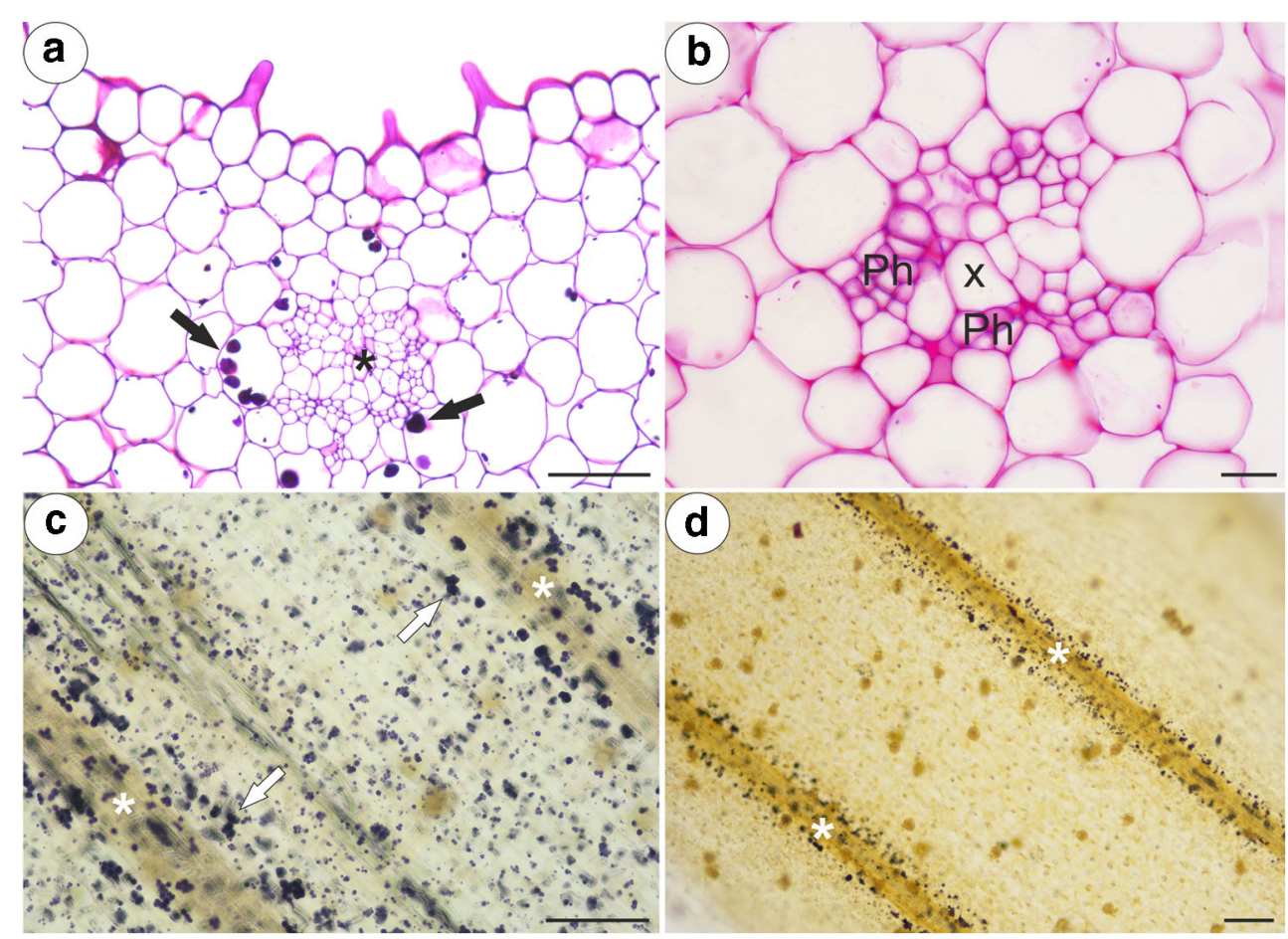

$15 \mathrm{~min}$ at each concentration and kept overnight in absolute ethanol. Later, the samples were infiltrated for $1 \mathrm{~h}$ each in $3: 1$, 1:1 and 1:3 (v/v) mixtures of absolute ethanol and Technovit and then stored for $12 \mathrm{~h}$ in pure Technovit. The resin was polymerised by adding a hardener. The material was sectioned to $5 \mu \mathrm{m}$ thick using a rotary microtome (Microm, AdamasInstrumenten), stained with $0.1 \%$ toluidine blue $\mathrm{O}$ (TBO) and mounted in Entellan synthetic resin (Merck).
Fig. 4 Micromorphology and anatomy of a glandular trichome located on the outer surface of a P. moranensis spur. $\mathbf{a}, \mathbf{b}$

Micromorphology of the interior (S) and outer glandular trichomes of the spur (arrow); scale bar = $500 \mu \mathrm{m}$ and $100 \mu \mathrm{m}$, respectively. c Autofluorescence of the outer trichome cell wall; note the bright fluorescence showing the cell wall of the pedestal cell that is heavily impregnated with cutin (arrowhead); scale bar $=50 \mu \mathrm{m}$. d General morphology of an outer trichome with a secretion droplet (star) on the top; scale bar = $50 \mu \mathrm{m}$. e Anatomy of an outer trichome showing the basal cell $(\mathrm{Bc})$, stalk cell $(\mathrm{Sc})$ and trichome head $(\mathrm{H})$; scale bar $=10 \mu \mathrm{m}$
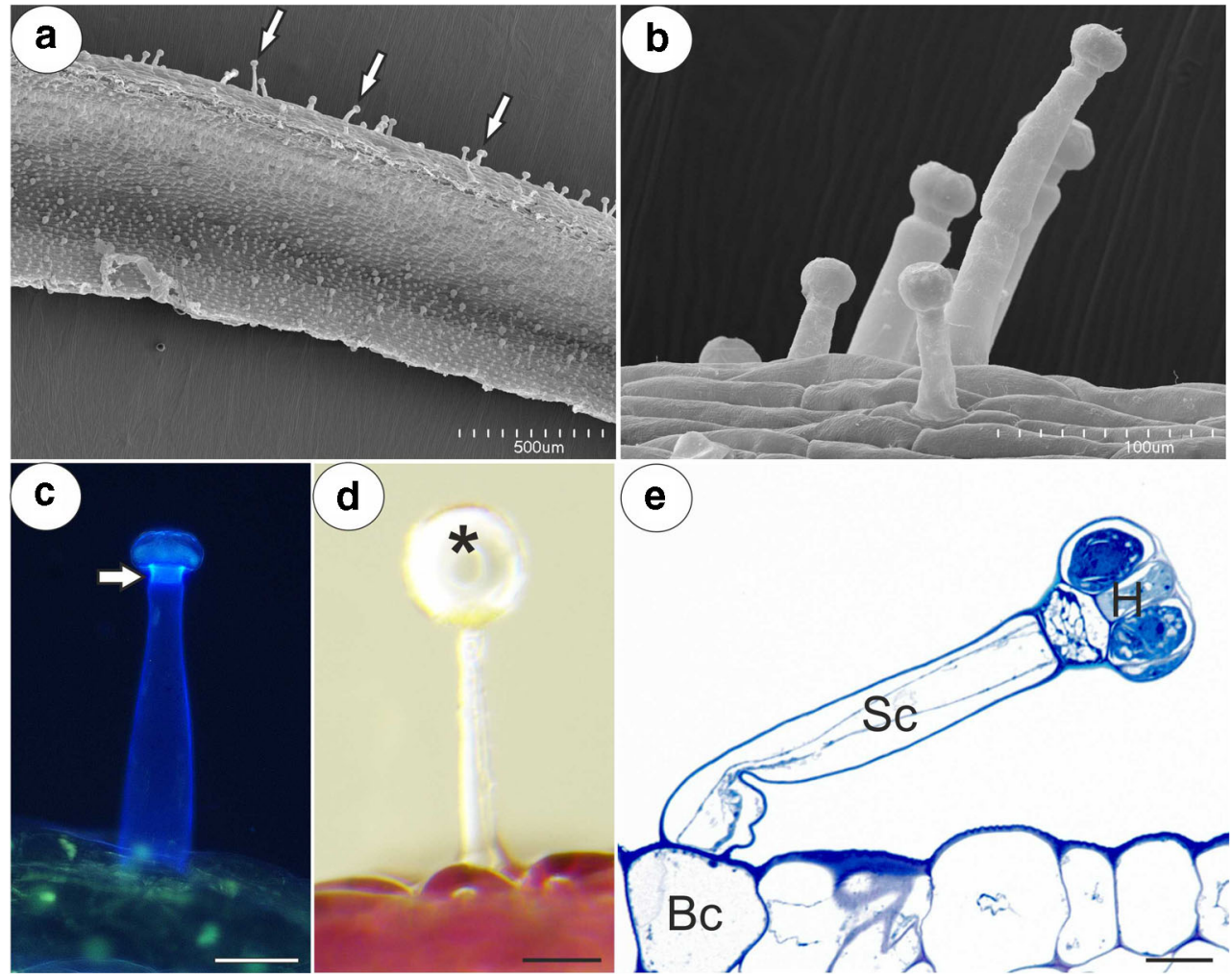
Fig. 5 Structure of the Pinguicula papillae. a, b Micromorphology of $P$. esseriana and

P. moctezumae papillae, respectively; note the papillae $(\mathrm{P})$ with an almost smooth cuticular surface (a) and cuticular striations (b). These striations were also observed on cuticular surface of glandular trichome stalk cell (Sc); scale bar $=20 \mu \mathrm{m}$ and $40 \mu \mathrm{m}$. c, d, respectively. Ultrastructure of P. moctezumae papillae; note the paracrystalline protein inclusion (Pi) in the nucleus $(\mathrm{N})$, the cell wall $(\mathrm{Cw})$ polysaccharide fibrillary network in the cuticle layer (arrow), lipid droplets (L) with mitochondria (M) in the cytoplasm and huge vacuoles $(\mathrm{V})$; scale $\mathrm{bar}=0.5 \mu \mathrm{m}$ and $0.8 \mu \mathrm{m}$, respectively

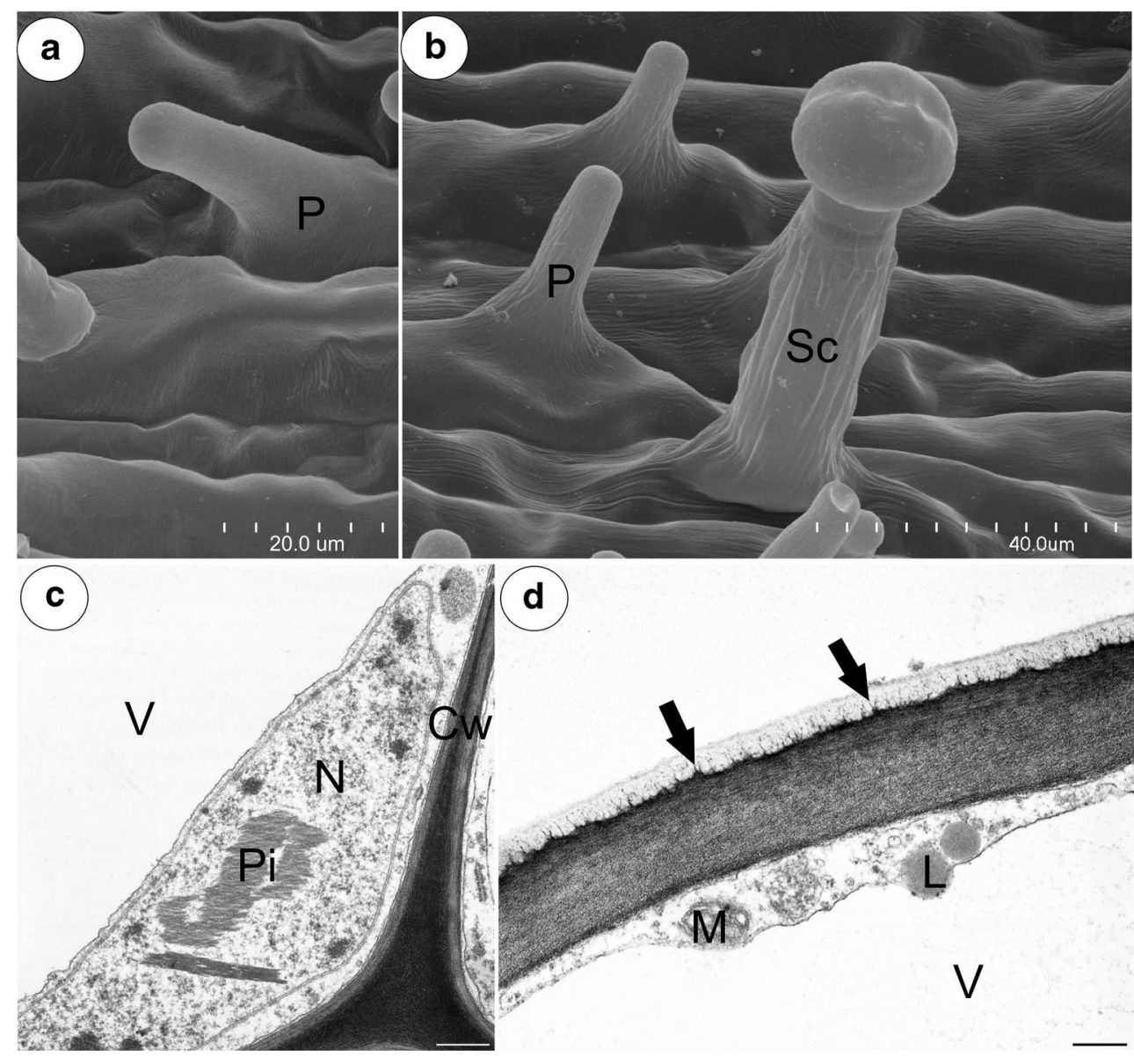

Living, non-fixed spurs were cut using a razor blade and observed under UV light using a Nikon Eclipse E400 microscope to determine any autofluorescence of the cuticle. In order to identify the main classes of the chemical compounds that are present in the spur tissues, histochemical procedures with the spurs of fresh or fixed flowers using Sudan III, Sudan Black B and Lugol's solution were performed to detect the total lipids, starch grains and proteins (Johansen 1940), respectively.

For the SEM, the spur traps were fixed (as above) and later dehydrated and critical point dried using $\mathrm{CO}_{2}$. They were then sputter-coated with gold and examined at an accelerating voltage of $20 \mathrm{kV}$ using a Hitachi S-4700 scanning electron microscope, which is housed in the Institute of Geological Sciences, Jagiellonian University in Kraków, Poland.

\section{Statistical analysis}

We measured the trichomes length and trichomes head diameter for each species (Table 1). The numbers of flowers used for measurements were three for $P$. moranensis, $P$. moctezumae, $P$. rectifolia and two for $P$. esseriana, $P$. emarginata. Each variable was tested using the Shapiro-
Wilk W-test for normality. The homogeneity of variance was assessed with Levene's test. Statistical differences in trichomes length, as well as trichomes head diameter between each Pinguicula species, were assessed using the KruskalWallis nonparametric one-way ANOVA, followed by multiple comparison of average ranks for all trials test. Statistical analyses were performed on raw data using Statistic 13 software (StatSoft Inc.). Data from measurements of trichomes length and head diameter were expressed in $\mu \mathrm{m}$ as mean \pm SD. Data were considered statistically significant at $* * p<0.01$ and $* * * p<0.001$.

\section{Results}

Any similar results for the five studied Pinguicula species were grouped and are presented together and the differences between them were highlighted in the text. We did not find the differences in the structure of flowers between typical and white-flowered forms of $P$. moranensis. The general anatomy of the spur was the same across the investigated species. In a transverse section, the wall of the spur was composed of several cell layers: the internal epidermis, layers of parenchyma 
Fig. 6 Morphology and anatomy of the examined Pinguicula stomata; note the guard cells (star) of the stoma with starch grains, the stoma pore (arrow), the air space below stoma (As) and a glandular trichome (T). a, b Morphology of $P$. rectifolia and P. moranensis stoma; scale bar $=$ $10 \mu \mathrm{m}$ and $25 \mu \mathrm{m}$, respectively. c. d PAS reaction of the $P$. esseriana and $P$. moranensis stoma; scale bar $=10 \mu \mathrm{m}$ and $50 \mu \mathrm{m}$, respectively. e, f Micromorphology of the $P$. rectifolia stoma; scale bar $=$ $50 \mu \mathrm{m}$ and $30 \mu \mathrm{m}$, respectively

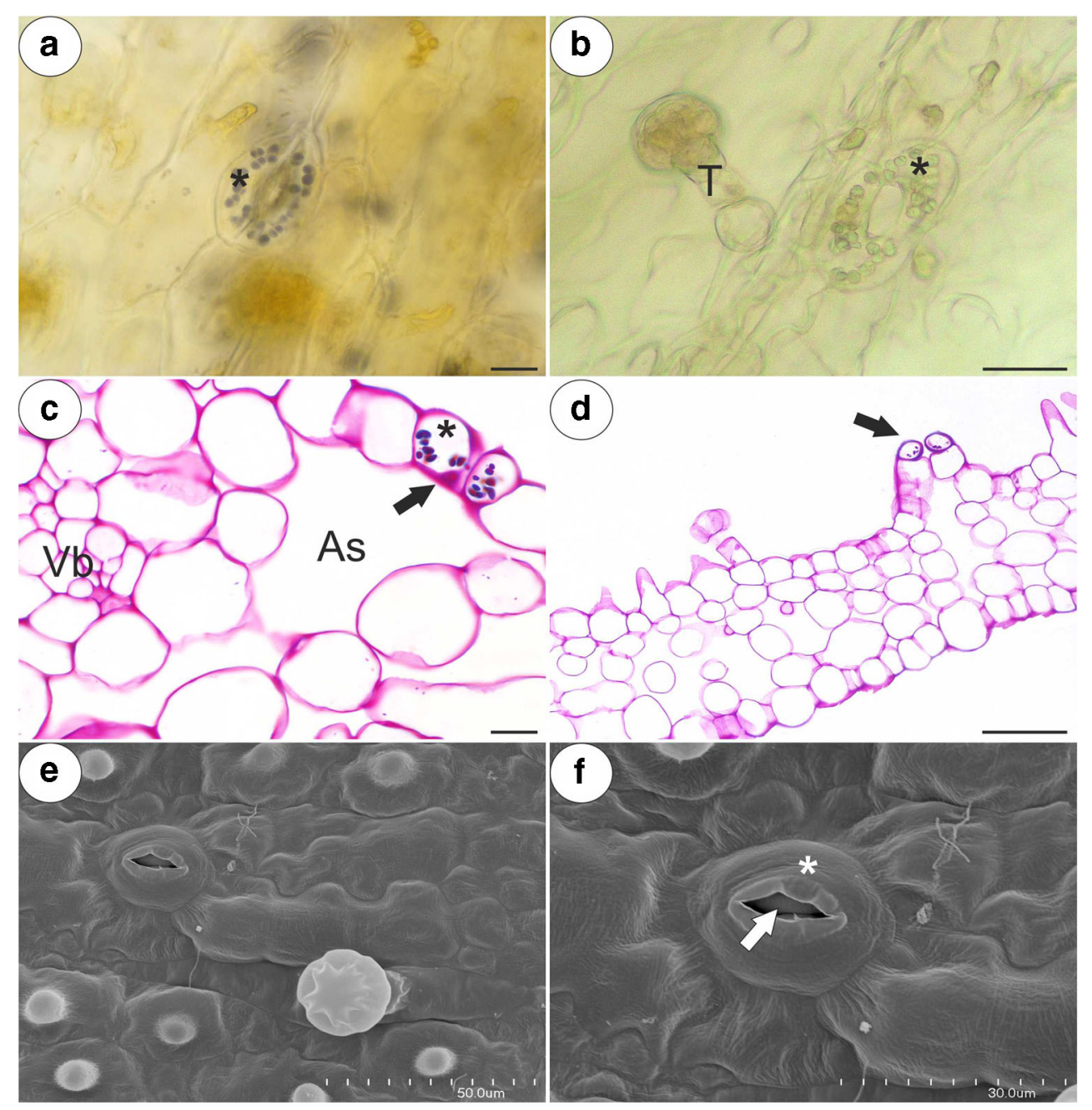

cells and the outer epidermis (Fig. 2a-f). The parenchyma cells were non-glandular. There were from three to eight layers of parenchyma and the number of layers depended on the species (for example, three to four in P. emarinata and four to eight in P. moctezumae). The collateral vascular bundles, each of which contained both a xylem and phloem, occurred in the ground parenchyma (Fig. 2a-f, Fig. 3a, b). The parenchyma cells of $P$. moctezumae, $P$. emarginata and $P$. rectifolia, which surround the vascular bundles, contained amyloplasts with large starch grains (Fig. 3a, d). In P. moctezumae, starch grains also occurred in the other parenchyma cells (Fig. 3c). In P. esseriana, the occurrence of starch grains depended on the flowers. Both the external and internal epidermis of the spur had capitate glandular trichomes (Fig. 4a). In all of the examined species, there were long-stalked glandular trichomes at the external spur surface (Fig. 4b-e). Each of this type of trichome consisted of a single basal cell, stalk cells (up to four - $P$. moranensis, which mostly occurred in one or two cells), a pedestal cell and a multi-celled head (Fig. 4e). The number of head cells varied in the species (up to 16 cells). The pedestal cell was a barrier cell with lateral walls impregnated with cutin. The head cells were glandular and produced droplets of secretion (Fig. 4d).

The inner epidermis formed short unicellular papillae that had an almost smooth surface (P. esseriana, Fig. 5a) or papillae with delicate striations (Fig. 5b). The papillae were highly vacuolated not glandular. The nuclei of the papillae had a paracrystalline protein inclusion (Fig. 5c). The papillae also had a thick cuticle. A polysaccharide fibrillary network of electron-dense ramification occurred in the cuticle layer (Fig. $5 \mathrm{~d})$. Stomata were observed in the inner epidermis of the spur (Fig. 6a-f). The stoma cells contained starch grains (Fig. 6ad). Sometimes, the stomata were elevated above the surface of the epidermis (Fig. 6d).

The trichomes of the nectary spur (Fig. 7a-0) were composed of a single basal cell, a stalk cell, a pedestal cell (barrier cell) and a multi-celled head (from four to eight cells) (Fig. 7c, e; Fig. 8a-c). In P. moctezumae, some trichomes were sessile and there was no stalk cell (Fig. 7a). Both the basal cell and stalk cell were highly vacuolated (Fig. 9a, b). The length and diameter of the trichome heads are listed in Table 1. Measurements of glandular trichomes length and trichomes 


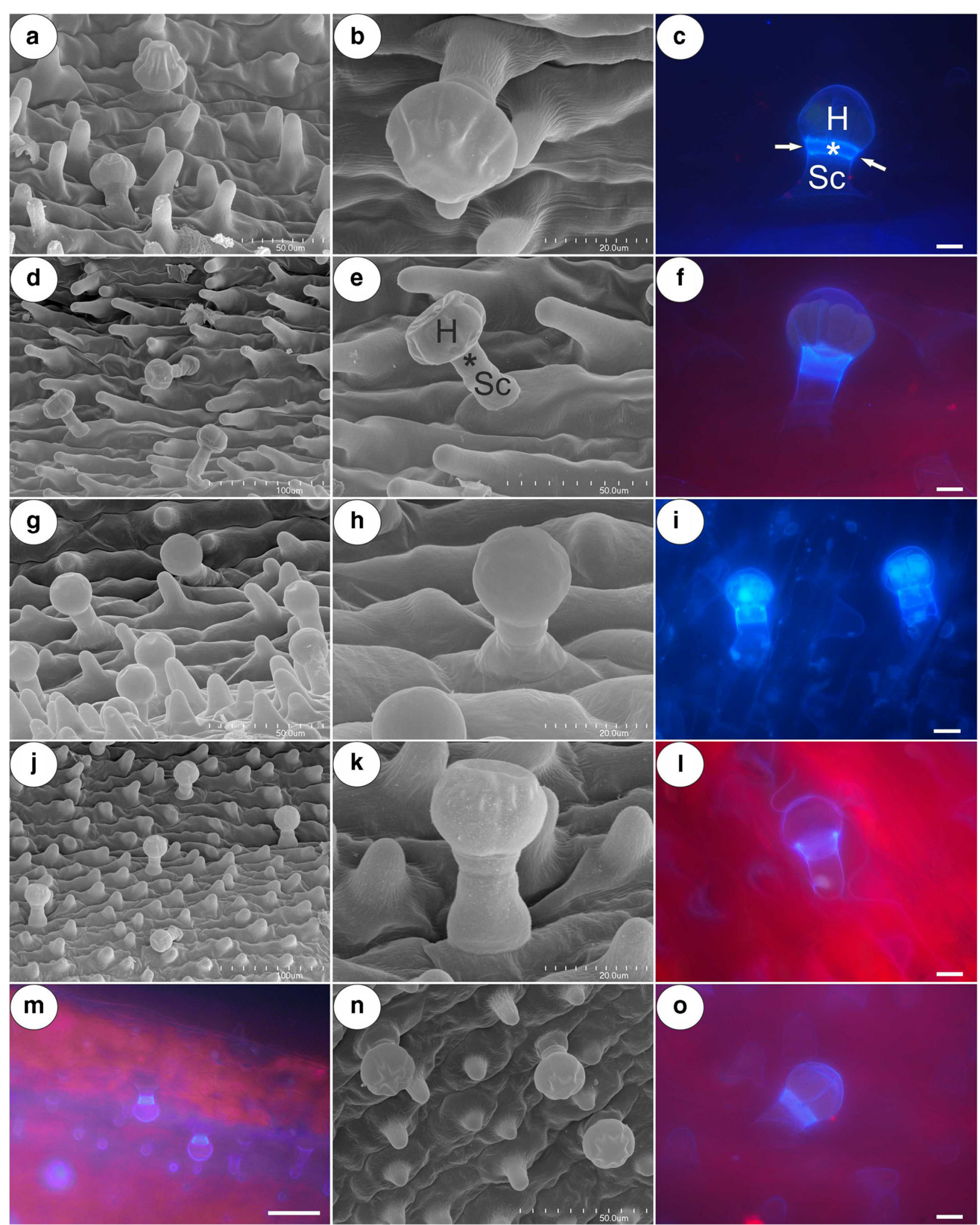

Fig. 7 Micromorphology and autofluorescence of the glandular trichomes of the examined Pinguicula species; note the stalk cell (Sc), trichome head $(\mathrm{H})$ and bright fluorescence showing the cell wall (arrow) of pedestal cell that is heavily impregnated with cutin (star). a-c P. moctezumae, scale bar $=50 \mu \mathrm{m}, 20 \mu \mathrm{m}, 10 \mu \mathrm{m}$, respectively. $\mathbf{d}-\mathbf{f}$
P. esseriana, scale bar $=100 \mu \mathrm{m}, 50 \mu \mathrm{m}, 10 \mu \mathrm{m}$, respectively. $\mathbf{g}-\mathbf{i}$ P. emarginata, scale bar $=50 \mu \mathrm{m}, 20 \mu \mathrm{m}, 10 \mu \mathrm{m}$, respectively. $\mathbf{j}-\mathbf{I}$ P. moranensis, scale bar $=100 \mu \mathrm{m}, 20 \mu \mathrm{m}, 10 \mu \mathrm{m}$, respectively. $\mathbf{m}-\mathbf{0}$ P. rectifolia, scale bar $=50 \mu \mathrm{m}, 50 \mu \mathrm{m}, 10 \mu \mathrm{m}$, respectively 


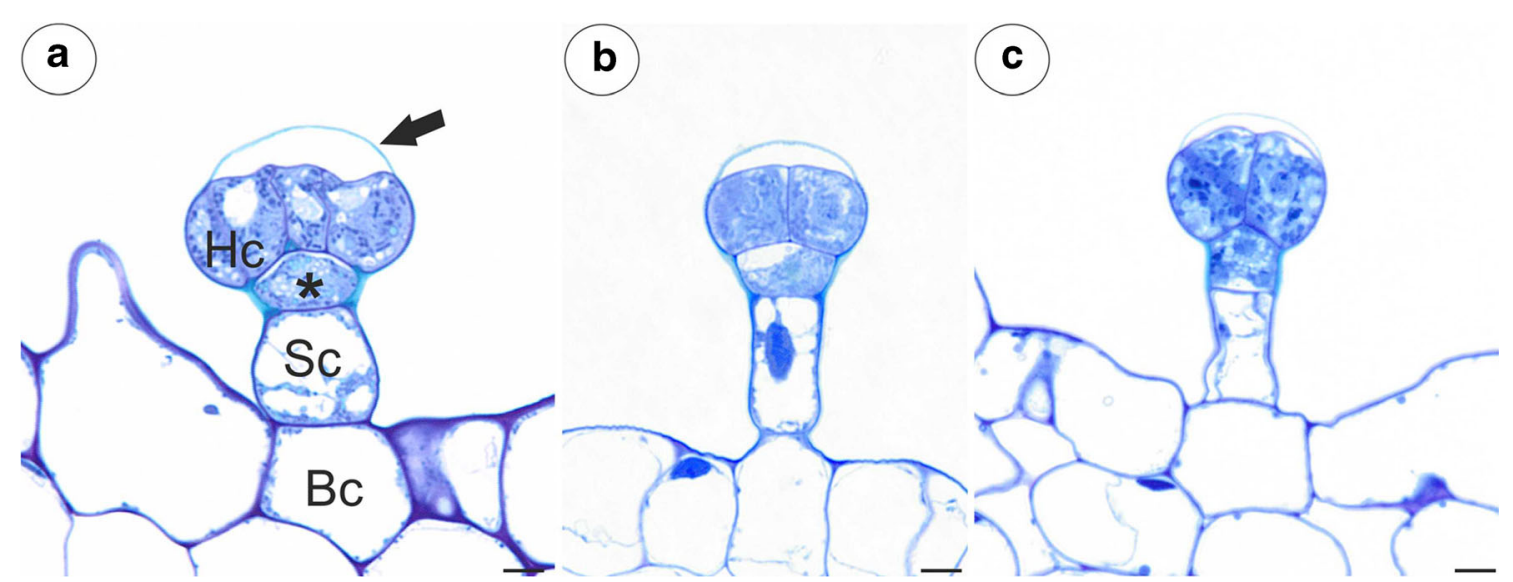

Fig. 8 Anatomy of the glandular trichomes of the examined Pinguicula species. a P. moctezumae; Part of a section through the glandular trichome showing the basal cell $(\mathrm{Bc})$, stalk cell $(\mathrm{Sc})$, pedestal cell (star), head cell

(Hc) and cuticle separating from the cell wall (arrow); scale bar $=5 \mu \mathrm{m} . \mathbf{b}$ P. moranensis; scale bar $=5 \mu \mathrm{m}$. c $P$. emarginata; scale bar $=5 \mu \mathrm{m}$

head diameter revealed that the longest trichomes with widest trichomes head inside spur occurred in P. esseriana and $P$. moranensis. Analyses of trichomes length show the significant differences occurred in $P$. esseriana and $P$. moranensis comparing with $P$. moctezumae, $P$. rectifolia and P. emarginata $(* * * p<0.001)$ [supplementary Material]. We also observed marked differences in the trichomes head diameter between $P$. esseriana and $P$. moranensis comparing with $P$. moctezumae $(* * p<0.01), P$. rectifolia and $P$. emarginata $(* * * p<0.001)$ [supplementary Material]. P. moctezumae had wider trichomes head comparing with $P$. emarginata $(* * p<0.01)$.

The outer wall of the basal cell developed a cuticle. The lateral wall of the stalk cell developed a distinct cuticle cell wall layer (Fig. 9c). The pedestal cell had a thick radial (lateral) wall, which was heavily impregnated with cutin (Fig. 9d). In the radial cell wall, two layers were distinguished (there were differences in the cell impregnation). The inner surface of the radial cell wall had an undulating surface (Fig. 9d, e and g). The impregnation with cutin also occurred in a fragment of the transverse walls between the stalk cell and the pedestal cell (Fig. 9e) as well as in the fragments of the cell walls between the pedestal cell and the head cells (Fig. 9f). However, the transverse walls were thinner than the radial cell wall and electron dense. Plasmodesmata occurred in the transverse walls between the stalk cell and the pedestal cell (Fig. 9e) as well as in the transverse walls between the pedestal cell and the terminal cells (Fig. 9g). The nucleus of the pedestal cell was prominent (Fig. 9d). The cytoplasm contained many mitochondria (Fig. 9d, e and g) and profiles of the rough endoplasmic reticulum. Plastids and microbodies were also observed. The vacuoles formed a reticulate network (Fig. 9e). One of the most prominent features of the pedestal cell was the presence of lipid bodies (Fig. 9e-g). In the pedestal cells, there was a large accumulation of lipid bodies that were almost equal in size (Fig. 9f), whereas in others, there was one large lipid body and a few very small ones (Fig. 9g). This, could be connected with fusing of lipid bodies.

The head cells had a dense cytoplasm (Fig. 10a) with prominent nuclei with a paracrystalline protein inclusion (Fig. 10a and Fig. 11a). The cuticle became distended and separated from the cell walls and formed a subcuticular space at top part of the head (Fig. 10b). There was a polysaccharide fibrillary network of electron-dense ramification in the cuticle layer (Fig. 10b). Mitochondria were very numerous with well-developed cristae as view on the transversal section (Fig. 10c-f) and sometimes, they were cupshaped (Fig. 10c). Plastids were numerous and were oval-, dumbbell- or cup-shaped as view on the transversal section (Fig. 10d, e and Fig. 11c). They had small starch grains (P. moctezumae, P. moranensis, P. rectifolia; (Fig. 10d)) and electron-dense inclusions ( $P$. emarginata). The cytoplasm contained small lipid bodies, small dictyosomes (Fig. 10d-f) and microbodies (Fig. 11a). The vacuoles formed a reticulate network (Fig. 10f) or the vacuole was large. The vacuole contained some membranous material (Fig. 11c). In the periplasmic space (between the plasmalemma and the cell wall), there were vesicles. A large accumulation of vesicles and membranous material was sometimes observed in the periplasmic space (Fig. 11a). The fusion of a large vesicle that was connected to a vacuole that contained membranous material with plasmalemma was also observed (Fig. 11b). In P. emarginata and $P$. esseriana, the head cells were transfer cells; wall ingrowths occurred on the outer cell walls and on the transverse cell walls (Fig. 11c, d). In P. esseriana, the cell wall ingrowths were better developed (Fig. 11d) than in P. emarginata (Fig. 11c). 

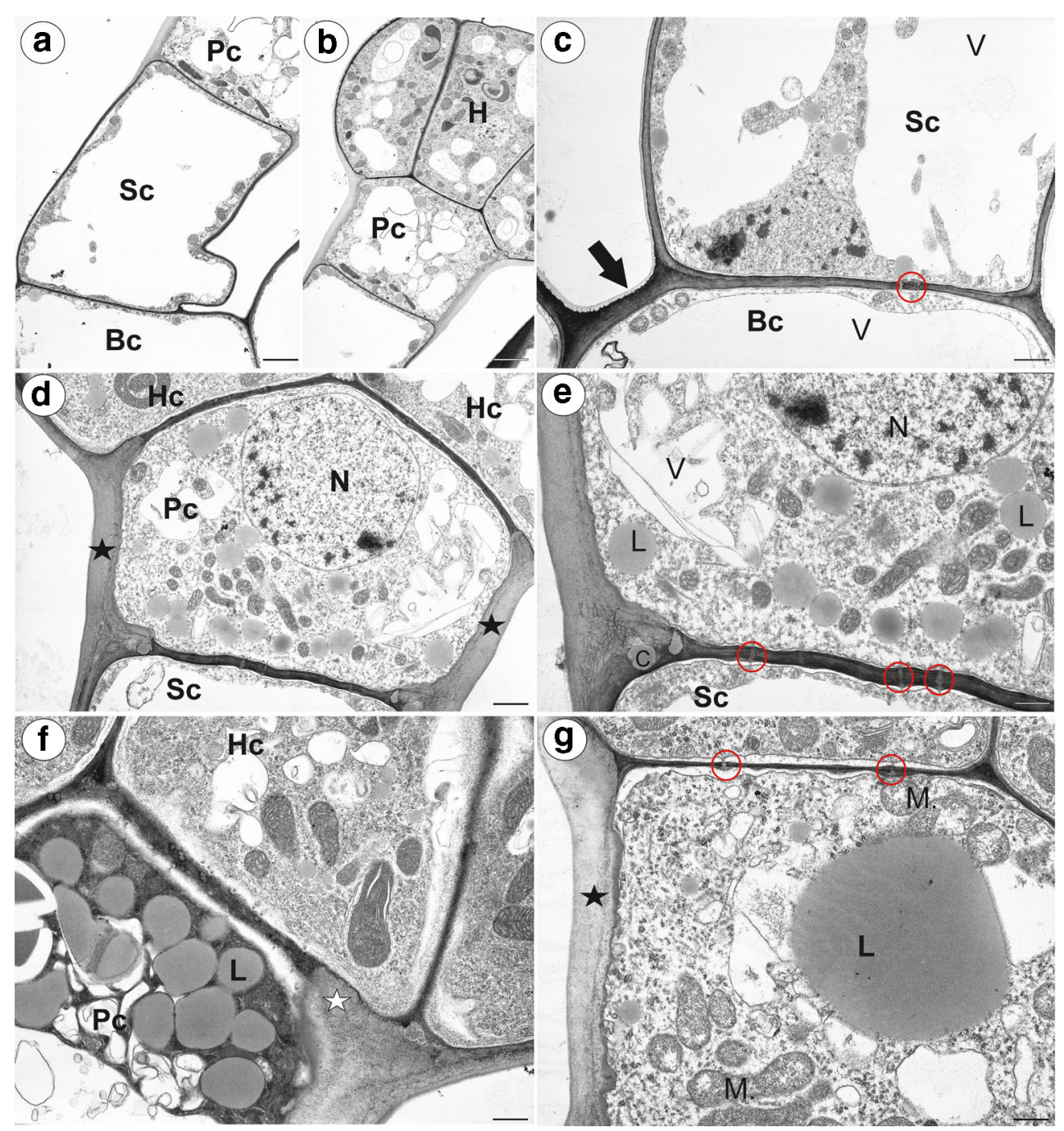

Fig. 9 Ultrastructure of the nectary trichomes of Pinguicula; $\mathbf{a}, \mathbf{b}$ $P$. emarginata ultrastructure of whole nectary trichome: the basal cell $(\mathrm{Bc})$, stalk cell $(\mathrm{Sc})$, pedestal cell $(\mathrm{Pc})$, head $(\mathrm{H})$; scale bar $=2.7 \mu \mathrm{m}$ and scale bar $=3.4 \mu \mathrm{m}$. c $P$. moctezumae ultrastructure of the basal $(\mathrm{Bc})$ and stalk cells ( $\mathrm{Sc}$ ): the cuticle of basal cell (arrow), plasmodesmata (red circle), vacuole $(\mathrm{V}) ;$ scale bar $=1.6 \mu \mathrm{m}$. d-e P. moctezumae ultrastructure of the trichome cells; note that the lateral cell wall of the pedestal cell (Pc) was heavily impregnated with cutin (star): nucleus $(\mathrm{N})$, vacuole (V), plasmodesmata (red circle), impregnation with cutin in a fragment of

the transverse walls between the stalk cell and the pedestal cell $(\mathrm{C})$, head cell $(\mathrm{Hc})$, stalk cell $(\mathrm{Sc})$; scale bar $=1.6 \mu \mathrm{m}$ and scale $\mathrm{bar}=0.8 \mu \mathrm{m}$. $\mathbf{f}$ $P$. moctezumae accumulation of lipid bodies (L) in the pedestal cell: pedestal cell $(\mathrm{Pc})$, head cell $(\mathrm{Hc})$, impregnation with cutin in a fragment of the transverse walls between the pedestal cell and head cell (white star); scale bar $=0.8 \mu \mathrm{m}$. g P. moranensis. Accumulation of lipid bodies (L) in the pedestal cell: mitochondria (M), plasmodesmata (red circle) between the pedestal cell and head cells, the lateral cell wall of the pedestal cell impregnated with cutin (star); scale bar $=0.9 \mu \mathrm{m}$

\section{Discussion}

The results presented here show a conservative nectary trichome structure and spur anatomy in different Pinguicula species from Mexico. These similarities might stem from the fact that the examined species are closely related; thus, some traits may represent synapomorphies for the group. They are grouped into one clade-Mexican-Central AmericanCaribbean Clade I (Cieslak et al. 2005). From examined species, pollinators (butterflies) were recorded only for P. moranensis (Villegas and Alcalá 2018); however, flower

structure (coloured flowers with long and thin spurs) suggests that also other examined species are pollinated by butterflies.

The gross structural similarities between the species that were examined were as follows: the spur anatomy, the occurrence of papillae, the architecture of the nectary trichomes and the ultrastructure characters of the trichome cells. However, there were some differences in the spur length (Fig. 1), the size of trichomes in the spurs, the occurrence starch grains in the spur parenchyma (they were not detected in P. moranensis) and the occurrence of cell wall ingrowths in the terminal cells of the nectary trichomes. In the nectaries, starch reserves are utilised as a source of carbohydrates to produce nectar (Nepi 
Fig. 10 Ultrastructure of head cells of the Pinguicula nectary trichomes. a, b Ultrastructure of the head cells of P. moranensis: head cell $(\mathrm{Hc})$, pedestal cell $(\mathrm{Pc})$, subcuticular space $(\mathrm{Sc})$, cuticle (C), polysaccharide fibrillary network in the cuticle layer (red eclipsed); scale bar $=1.7 \mu \mathrm{m}$ and scale bar $=1 \mu \mathrm{m}$. c, d

Ultrastructure of the head cells of P. moctezumae; note the numerous mitochondria some of which are cup-shaped (arrow), lipid droplets (L), plastids with starch (S), nucleus $(\mathrm{N})$; scale bar $=1 \mu \mathrm{m}$ and scale bar $=$ $1.1 \mu \mathrm{m}$. e A part of a section through the head cell of P. emarginata; note the cupshaped plastid, inclusion in plastid (star), mitochondria with welldeveloped cristae (M), small dictyosomes (red arrow), vacuole (V); scale bar $=1.1 \mu \mathrm{m}$. f A reticulate vacuole in the head cell of P. moctezumae: vacuole (V), mitochondria $(\mathrm{M})$; scale bar $=$ $0.8 \mu \mathrm{m}$

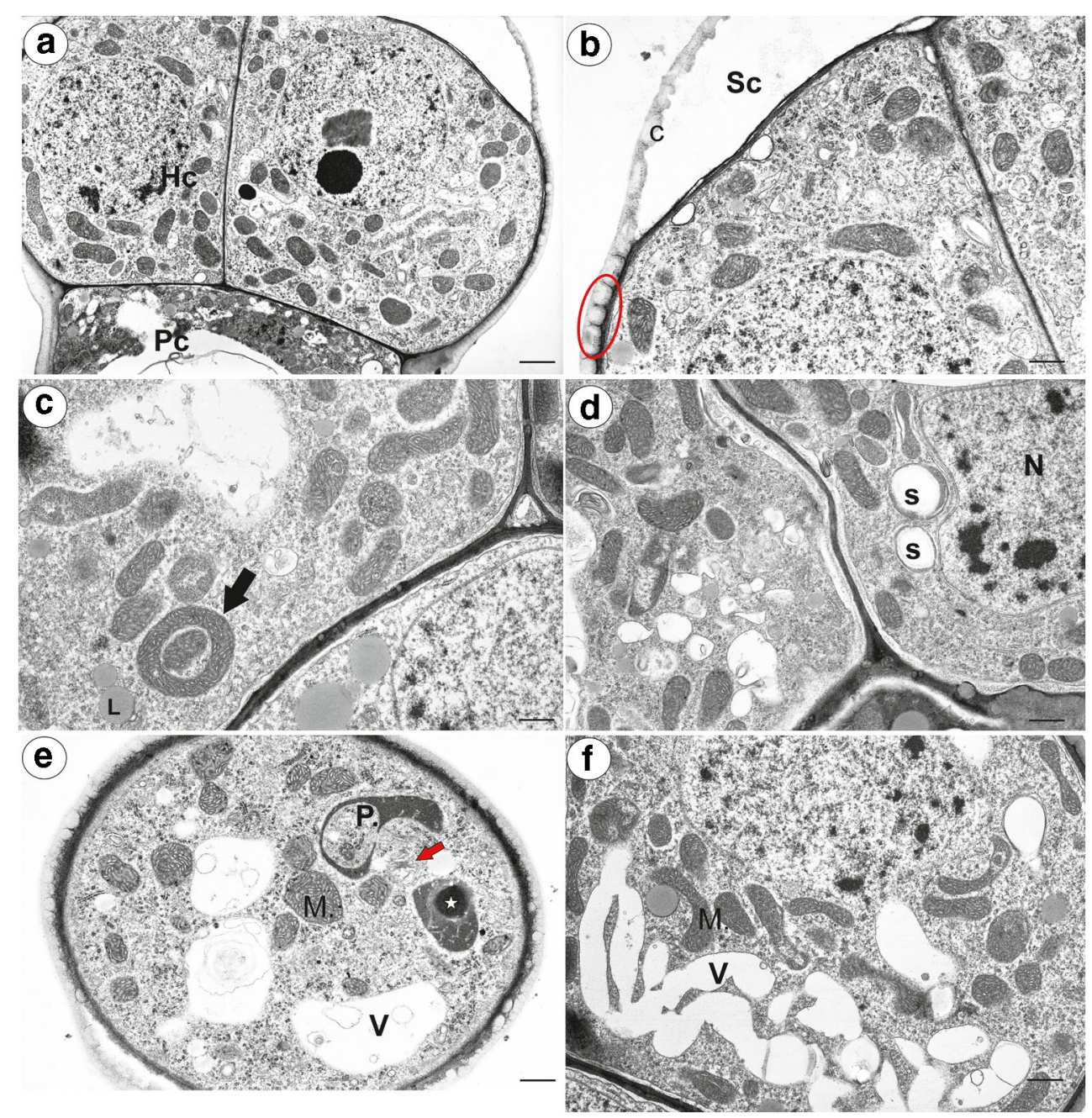

2007); thus, the variations in the amount of starch among the examined Pinguicula species, as well as the lack of starch in the spurs of $P$. moranensis, might be caused by its hydrolysis.

We noted correlation between the length of the spur trichomes and the width of their heads. The species that had longest trichome stalk have also the largest diameter of trichome heads (P. esseriana and P. moranensis). It is interesting that the spur trichomes length and their head diameter were not correlated with the size of flowers (also spur length). Pinguicula rectifolia with large flowers had trichome sizes similar to P. emarginata, which had small flowers. We found a clear difference in the length of the spur trichomes as well as the width of their heads between P. moranensis and $P$. rectifolia. This characters may be an important diagnostic feature helpful in the determination of these species, especially that some authors included $P$. rectifolia in $P$. moranensis complex (e.g. Roccia et al. 2016); however, future analysis of more plant material from different populations is needed.

The spur anatomy of the Pinguicula that were examined here is very similar to Utricularia (Płachno et al. 2016, 2017, $2018,2019 b, c)$. In both genera, there are collateral vascular bundles in the nectaries (spurs). Papillose surfaces of the internal spur epidermis occur in the spurs of all Lentibulariaceae genera (Utricularia - Clivati et al. 2014; Płachno et al. 2016, 2017, 2018; Genlisea-Aranguren et al. 2018). However, there is variability in the case of the occurrence of cuticular striations among the species.

Stomata are described on the surfaces of the internal spur epidermis for Lentibulariaceae for first time. In many plants, nectaries with modified stomata ('nectarostomata') occur, which are used to release nectar (e.g. Davis and Gunning 1992; Davies et al. 2005; Wist and Davis 2006; Nepi 2007; Pacini and Nepi 2007). In some species, nectar is secreted by both trichomes and modified stomata in spur in the same plant (e.g. in Tropaeolun majus; Rachmilevitz and Fahn 1975). However, there are glandular parenchyma in these nectaries that produce nectar. In the examined flowers of Pinguicula, the spur parenchyma cells are not glandular; thus, the stomata probably do not participate in the release of nectar. Explaining their function requires further research.

Similar nectary capitate trichomes, as are described here, have been recorded in the spurs of various Utricularia species 


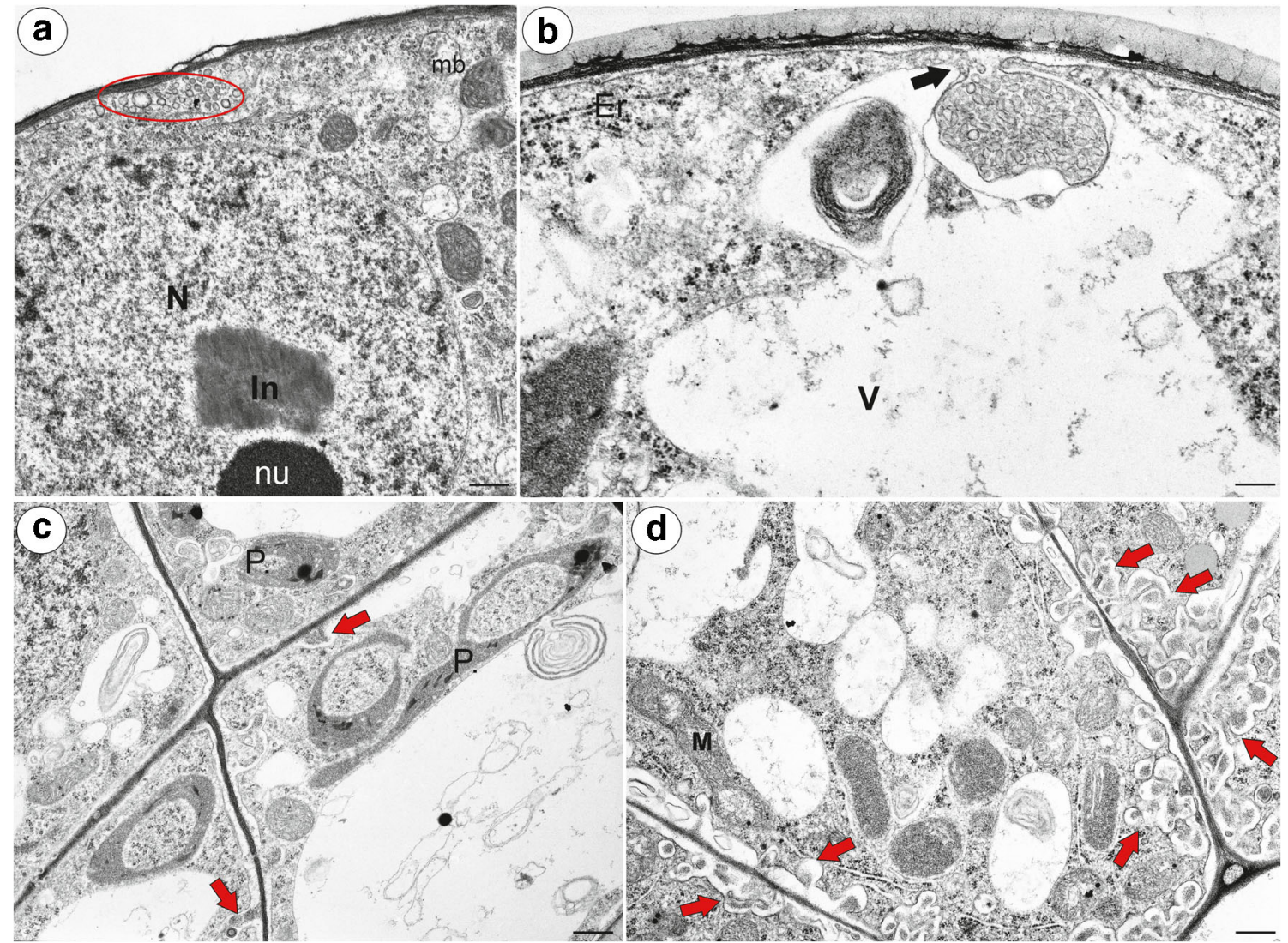

Fig. 11 Ultrastructure of the head cells of the Pinguicula nectary trichomes. a Ultrastructure of the head cell of P. moranensis; note the large accumulation of membranous material in the periplasmic space (red eclipsed): nucleus $(\mathrm{N})$, nucleolus $(\mathrm{nu})$, paracrystalline protein inclusion (In); scale bar $=0.8 \mu \mathrm{m}$. b Ultrastructure of the head cell of $P$. emarginata; note the fusion of the large vesicle connected to the vacuole, which

(Farooq 1963; Farooq and Siddiqui 1966; Clivati et al. 2014; Płachno et al. 2016, 2017, 2018, 2019b, c) and Genlisea violacea (Aranguren et al. 2018). Unfortunately, there are no published data about the ultrastructure of the nectary trichomes in Genlisea. The ultrastructural similarities between the nectary trichomes in Pinguicula and Utricularia are as follows: a highly vacuolated basal cell, and sometimes, also a stalk cell; a pedestal with impregnated with cutin radial wall (Casparian strip); in the terminal cells: the dense cytoplasm contains large amount of organelles - numerous mitochondria and multi-shaped plastids (which evidence a highly metabolic function); a paracrystalline protein inclusion in the nucleus and the occurrence of cell wall ingrowths, a thick cuticle and a subcuticular space for accumulating nectar. The ultrastructure characters of the Pinguicula nectary trichome terminal cells are typical for nectaries (see Nepi 2007; Pacini and Nepi 2007).

In the cuticular layer of head cells in the examined Pinguicula, there were polysaccharide micro-canals, which are hydrophilic pathways that most probably form pathways for the release of secretions (Paiva 2016, 2017). Such a contains membranous material, with plasmalemma (arrow); endoplasmic reticulum (Er), vacuole $(\mathrm{V})$; scale bar $=0.5 \mu \mathrm{m}$. c Ultrastructure of the head cells of $P$. emarginata; note the small cell wall ingrowths (red arrows); cup-shaped plastid $(\mathrm{P})$; scale $1 \mathrm{bar}=\mu \mathrm{m}$. d Ultrastructure of the head cells of $P$. esseriana; note the well-developed cell wall ingrowths (red arrows); scale bar $=0.9 \mu \mathrm{m}$

structure has been described in the cells of various nectary types in many species (e.g. Stpiczyńska 2003; Wist and Davis 2006; Rocha and Machado 2009; Antoń and Kamińska 2015; Weryszko-Chmielewska and Chwil 2016) as well as in other plant glandular structures-osmophores (García et al. 2007; Płachno et al. 2010; Kowalkowska et al. 2012, 2014, 2017; Paiva et al. 2019), collectors (Tresmondi et al. 2017) and trichomes, which produce a lipophilic secretion (Machado et al. 2017; Muravnik et al. 2019). Interestingly, we found polysaccharide micro-canals in the cuticular layer of the spur papillae. These structures were recorded in the spur papillae of Utricularia (Płachno et al. 2016). However, in both Pinguicula and Utricularia, the papillae in the mature spur are not glandular. Therefore, we speculate that the occurrence of these micro-canals may indicate that the papillae participate in the reabsorption of nectar.

We observed lipid droplets in the cytoplasm in the nectary trichome cells. Lipid droplets have previously been recorded in the cytoplasm in the nectary trichome cells of Utricularia multifida (Płachno et al. 2019c). Machado et al. (2017) proposed that the occurrence of lipid droplets in the cytoplasm in 
the nectary cells might indicate that the nectar is enriched with lipids. However, we observed a large accumulation of lipid droplets in the pedestal cells, which play the role of barrier cells. A similar accumulation of lipids was recorded in the pedestal cells of trichomes of Utricularia turions (Płachno et al. 2014), and therefore, the occurrence of lipid droplets in the pedestal cells might not be directly connected with the secretion of nectar.

Płachno et al. $(2018,2019 \mathrm{c})$ proposed that the nectar secretion in Utricularia occurs via an eccrine mode. This type of nectar secretion probably occurs in $P$. esseriana due to its well-developed cell wall ingrowths. However, in other Pinguicula species (P. moctezumae, P. moranensis) that have been examined, there are no cell wall ingrowths in the nectary glandular cells or, if they are present, they are very weakly developed ( $P$. emarginata). In these species, we observed material in the periplasmic space as well as the fusion of a large vesicle that was connected to the vacuole that contained membranous material with the plasmalemma (Fig. 11b). Paiva (2016) proposed cyclic mechanical actions of the protoplast in the secretory cells, which "in the form of successive cycles of contraction and expansion, causes the material accumulated in the periplasmic space to cross the cell wall and the cuticle" (Pavia 2016, pg. 533). He proposed that during the fusion of the vacuolar and plasma membranes, the vacuolar content is released into the periplasmic space. Thus, we speculate that in some Pinguicula species, the secretion of nectar may occur via a mode other than the eccrine mode. However, this problem requires further research, including studies of the various stages of the development of the nectary Pinguicula trichomes.

To conclude, we show that both the nectary trichome structure and the spur anatomy in different Pinguicula species from Mexico are conservative. Similar nectary capitate trichomes, as are described here, have been recorded in the spurs of species from other Lentibulariaceae genera. There are many ultrastructural similarities between the nectary trichomes in Pinguicula and Utricularia.

Acknowledgments We thank horticulturist Lucyna Kurleto for her conscientious care of the living collection of carnivorous plants that are located in the Botanical Garden of Jagiellonian University in Kraków.

Funding information This research was supported financially by the Ministry of Science and Higher Education of Poland as part of the statutory activities of the Department of Plant Cytology and Embryology, Institute of Botany, Faculty of Biology, Jagiellonian University in Kraków (K/N18/DBS/000002 and partially N18/MNS/000012) and also of the Department of Animal Histology and Embryology, Faculty of Biology and Environmental Protection, University of Silesia in Katowice.

\section{Compliance with ethical standards}

Conflict of interest The authors declare that they have no conflicts of interest.
Open Access This article is distributed under the terms of the Creative Commons Attribution 4.0 International License (http:// creativecommons.org/licenses/by/4.0/), which permits unrestricted use, distribution, and reproduction in any medium, provided you give appropriate credit to the original author(s) and the source, provide a link to the Creative Commons license, and indicate if changes were made.

\section{References}

Abrahamczyk S, Kessler M, Hanley D, Karger DN, Müller MPJ, Knauer AC, Keller F, Schwerdtfeger M, Humphreys AM (2017) Pollinator adaptation and the evolution of floral nectar sugar composition. $\mathrm{J}$ Evol Biol 30(1):112-127

Adlassnig W, Lendl T, Peroutka M, Lang I (2010) Deadly glue-adhesive traps of carnivorous plants. In: Byern J, Grunwald I (eds) Biological adhesives system. Springer, Vienna, pp 15-28

Adler PH, Malmqvist B (2004) Predation on black flies (Diptera: Simuliidae) by the carnivorous plant Pinguicula vulgaris (Lentibulariaceae) in northern Sweden. Entomol Fennica 15(2): 124-128

Alcalá RE, Domínguez CA (2003) Patterns of prey capture and prey availability among populations of the carnivorous plant Pinguicula moranensis (Lentibulariaceae) along an environmental gradient. Am J Bot 90(9):1341-1348

Alcalá RE, Domínguez CA (2005) Differential selection for carnivory traits along an environmental gradient in Pinguicula moranensis. Ecology 86(10):2652-2660

Antoń S, Kamińska M (2015) Comparative floral spur anatomy and nectar secretion in four representatives of Ranunculaceae. Protoplasma 252(6):1587-1601

APG IV (2016) An update of the Angiosperm Phylogeny Group classification for the orders and familie of flowering plants: APG IV. Bot J Linn Soc 181(1):1-20

Aranguren Y, Płachno BJ, Stpiczyńska M, Miranda VFO (2018) Reproductive biology and pollination of the carnivorous Genlisea violaceae (Lentibulariaceae). Plant Biol 20(3):591-601

Beck SG, Fleischmann A, Huaylla H, Müller KF, Borsch T (2008) Pinguicula chuquisacensis (Lentibulariaceae), a new species from the Bolivian Andes, and first insights on phylogenetic relationships among South American Pinguicula. Willdenowia 38(1):201-212

Casper SJ (1966) Monographie der Gattung Pinguicula L. Bibliotheca Botanica 127-128:1-209

Cieslak T, Polepalli JS, White A, Muller K, Borsch T, Barthlott W, Steiger J, Marchant A, Legendre L (2005) Phylogenetic analysis of Pinguicula (Lentibulariaceae): chloroplast DNA sequences and morphology support several geographically distinct radiations. Am J Bot 92:1723-1736

Clivati D, Cordeiro GD, Płachno BJ, Miranda VFO (2014) Reproductive biology and pollination of Utricularia reniformis a.St.-Hil. (Lentibulariaceae). Plant Biol 16(3):677-682

Darnowski D, Bauer U, Moran J, Horner J, Méndez M, Płachno BJ (2018) Chapter 21. Prey selection and specialization by carnivorous plants. In: Ellison AM, Adamec L (eds) Carnivorous plants: physiology, ecology and evolution. Oxford University Press, pp 285-293

Davies KL, Stpiczyńska M, Gregg A (2005) Nectar-secreting floral stomata in Maxillaria anceps Ames \& C. Schweinf. (Orchidaceae). Ann Bot 96(2):217-227

Davis AR, Gunning BES (1992) The modified stomata of the floral nectary of Vicia faba L. 1. Development, anatomy and ultrastructure. Protoplasma 166(3-4):134-152

Farooq M (1963) Trichomes on the floral parts of Utricularia. J Indian Bot Soc 45:242-248 
Farooq M, Siddiqui SA (1966) Trichomes on the flowers of Utricularia. Beitr Biol Pflanzen 42:353-361

Fischer E, Barthlott W, Seine R, Theisen I (2004) Lentibulariaceae. In: Kadereit JW (ed) Flowering plants Dicotyledons. The families and genera of vascular plants, vol 7. Springer, Berlin, Heidelberg

Fleischmann A (2012) Dissertation, LMU München: Faculty of Biology. Phylogenetic relationships, systematics, and biology of carnivorous Lamiales, with special focus on the genus Genlisea (Lentibulariaceae). 2012, http://edoc.ub.uni-muenchen.de/14964/. Accessed 23 June 2019

Fleischmann A, Roccia A (2018) Systematics and evolution of Lentibulariaceae: I. Pinguicula. In: Ellison AM, Adamec L (eds) Carnivorous plants: physiology, ecology and evolution. Oxford University Press, pp 70-80

Fleischmann A, Schäferhoff B, Heubl G, Rivadavia F, Barthlott W, Müller KF (2010) Phylogenetics and character evolution in the carnivorous plant genus Genlisea A. St.-Hil. (Lentibulariaceae). Mol Phylogenet Evol 56(2):768-783

García AMT, Galati BG, Hoc PS (2007) Ultrastructure of the corona of scented and scentless flowers of Passiflora spp. (Passifloraceae). Flora Morphol Distrib Funct Ecol Plants 202(4):302-315

Heslop-Harrison Y (1970) Scanning electron microscopy of fresh leaves of Pinguicula. Science 167(3915):172-174

Heslop-Harrison Y (2004) Pinguicula L. J Ecol 92:1071-1118

Heslop-Harrison Y, Heslop-Harrison J (1980) Chloride ion moment and enzyme secretion from the digestive glands of Pinguicula. Ann Bot 45(6):729-731

Humphrey CD, Pittman FE (1974) A simple methylene blue-azure Iibasic fuchsin stain for epoxy-embedded tissue sections. Stain Technol 49(1):9-14

Ibarra-Laclette E, Lyons E, Hernández-Guzmán G, Pérez-Torres CA, Carretero-Paulet L, Chang T-H, Lan T, Welch AJ, Abraham Juárez MJ, Simpson J, Fernández-Cortés A, Arteaga-Vázquez M, Góngora-Castillo E, Acevedo-Hernández G, Schuster SC, Himmelbauer H, Minoche AE, Xu S, Lynch M, Oropeza-Aburto A, Cervantes-Pérez SA, de Jesús O-EM, Cervantes-Luevano JI, Michael TP, Mockler T, Bryant D, Herrera-Estrella A, Albert VA, Herrera-Estrella L (2013) Architecture and evolution of a minute plant genome. Nature 498:94-98

Jensen WA (1962) Botanical histochemistry - principles and practice. University of California, Berkeley. W. H. Freeman and Company

Jobson RW, Playford J, Cameron KM, Albert VA (2003) Molecular phylogenetics of Lentibulariaceae inferred from plastid rps 16 intron and trnL-F DNA sequences: implications for character evolution and biogeography. Syst Bot 28(1):157-171

Johansen DA (1940) Plant microtechnique. McGraw-Hill Book Co., New York

Juniper BE, Robins RB, Joel DM (1989) The carnivorous plants. Academic Press, London

Karlsson PS, Nordell KO, Eirefelt S, Svensson A (1987) Trapping efficiency of three carnivorous Pinguicula species. Oecologica 73(4): $518-521$

Kowalkowska AK, Margońska HB, Kozieradzka-Kiszkurno M, Bohdanowicz J (2012) Studies on the ultrastructure of a threespurred fumeauxiana from of Anacamptis pyramidalis. Plant Syst Evol 298(6):1025-1035

Kowalkowska AK, Kozieradzka-Kiszkurno M, Turzyński S (2014) Morphological, histological and ultrastructural features of osmophores and nectary of Bulbophyllum wendlandianum (Kraenzl.) Dammer (B. section Cirrhopetalum Lindl., Bulbophyllinae Schltr., Orchidaceae). Plant Syst Evol 301(2):609622

Kowalkowska AK, Turzyńska S, Kozieradzka-Kiszkurno M, Wiśniewska N (2017) Floral structure of two species of Bulbophyllum section Cirrhopetalum Lindl.: B. weberi Ames and
B. cumingii (Lindl.) Rchb. f. (Bulbophyllinae Schltr., Orchidaceae). Protoplasma 254(3):1431-1449

Lampard S, Gluch O, Robinson A, Fleischmann A, Temple P, McPherson S, Roccia A, Partrat E, Legendre L (2016) Pinguicula of Latina American. Redfern, Dorset pp 362

Legendre L (2000) The genus Pinguicula L. (Lentibulariaceae): an overview. Acta Bot Gallica 147(1):77-95

Lloyd FE (1942) The carnivorous plants. Chronica Botanica Company, Donald Publishing, Waltham

Machado SR, Souza CV, Guimarães E (2017) A reduced, yet functional, nectary disk integrates a complex system of floral nectar secretion in the genus Zeyheria (Bignoniaceae). Acta Bot Bras 31(3):344-357

Molano-Flores B, Primer S, Annis J, Feist MA, Coons J, Digges R (2018) Reproductive ecology of three rare North American Pinguicula species. Plant Spec Biol 33(2):129-139

Molau U (1993) Reproductive ecology of the three Nordic Pinguicula species (Lentibulariaceae). Nord J Bot 13(2):149-157

Müller K, Borsch T, Legendre L, Porembski S, Theisen I, Barthlott W (2004) Evolution of carnivory in Lentibulariaceae and the Lamiales. Plant Biol 6:477-490

Muravnik LE, Kostina OV, Mosina AA (2019) Glandular trichomes of the leaves in three Doronicum species (Senecioneae, Asteraceae): morphology, histochemistry, and ultrastructure. Protoplasma 256(3): 789-803

Nepi M (2007) Nectary structure and ultrastructure. In: Nicolson SW, Nepi M, Pacini E (eds) Nectaries and nectar. Springer, Rotterdam, pp 129-166

Nordin M (2015) Pinguicula alpina (alpine butterwort) on the Swedish island of Gotland: pollination and reproductive. (in Swedish). Thesis, Uppsala University, Disciplinary Domain of Science and Technology, Biology, Biology Education Centre. P. 29

Pacini E, Nepi M (2007) Nectar production and presentation. In: Nicolson SW, Nepi M, Pacini E (eds) Nectaries and nectar. Springer, Rotterdam, pp 167-214

Paiva EAS (2016) How do secretary products cross the plant cell wall to be released? A new hypothesis involving cyclic mechanical actions of the protoplast. Ann Bot 117(4):533-540

Paiva EAS (2017) How does the nectar of stomata-free nectaries cross the cuticle? Acta Bot Bras 31(3):525-530

Paiva EAS, Dötterl S, De-Paula OC, Schlindwein C, Souto LS, Vitarelli NC, da Silva CI, Mateus S, Alves-Dos-Santos I, Oliveira DMT (2019) Osmophores of Caryocar brasiliense (Caryocaraceae): a particular structure of the androecium that releases an unusual scent. Protoplasma 256:971-981. https://doi.org/10.1007/s00709-01901356-4

Płachno BJ, Kozieradzka-Kiszkurno M, Świątek P (2007) Functional ultrastructure of Genlisea (Lentibulariaceae) digestive hairs. Ann Bot 100(2):195-203. https://doi.org/10.1093/aob/mcm109

Płachno BJ, Świątek P, Szymczak G (2010) Can a stench be beautiful?osmophores in stem-succulent stapeliads (ApocynaceaeAsclepiadoideae-Ceropegieae-Stapeliinae). Flora Morphol Distrib Funct Ecol Plants 205(2):101-105. https://doi.org/10.1016/j.flora. 2009.01.002

Płachno BJ, Adamec L, Kozieradzka-Kiszkurno M, Świątek P, Kamińska I (2014) Cytochemical and ultrastructural aspects of aquatic carnivorous plant turions. Protoplasma 251(6):1449-1454. https://doi.org/ 10.1007/s00709-014-0646-8

Płachno BJ, Stpiczyńska M, Świątek P, Davies KL (2016) Floral micromorphology of the Australian carnivorous bladderwort Utricularia dunlopii, a putative pseudocopulatory species. Protoplasma 253(6): 1463-1473. https://doi.org/10.1007/s00709-015-0900-8

Płachno BJ, Stpiczyńska M, Davies KL, Świątek P, Miranda VFO (2017) Floral ultrastructure of two Brazilian aquatic-epiphytic bladderworts: Utricularia cornigera Studnička and U. nelumbifolia Gardner (Lentibulariaceae). Protoplasma 254(1):353-366. https:// doi.org/10.1007/s00709-016-0956-0 
Płachno BJ, Stpiczyńska M, Adamec L, Miranda VFO, Świątek P (2018) Nectar trichome structure of aquatic bladderworts from the section Utricularia (Lentibulariaceae) with observation of flower visitors and pollinators. Protoplasma 255(4):1053-1064. https://doi.org/10. 1007/s00709-018-1216-2

Płachno BJ, Świątek P, Miranda VFO, Stolarczyk P (2019a) The structure and occurrence of a velum in Utricularia traps (Lentibulariaceae). Front Plant Sci 10. https://doi.org/10.3389/fpls.2019.00302

Płachno BJ, Stpiczyńska M, Świątek P, Lambers H, Miranda VFO, Nge FJ, Stolarczyk P, Cawthray GR (2019b) Floral micromorphology of the bird-pollinated carnivorous plant species Utricularia menziesii R.Br. (Lentibulariaceae). Ann Bot 123(1):213-220. https://doi.org/ 10.1093/aob/mcy163

Płachno BJ, Stpiczyńska M, Świątek P, Lambers H, Cawthray GR, Nge FJ, Silva SR, Miranda VFO (2019c) Floral micromorphology and nectar composition of the early evolutionary lineage Utricularia (subgenus Polypompholyx, Lentibulariaceae). Protoplasma. https:// doi.org/10.1007/s00709-019-01401-2

Poppinga S, Weisskopf C, Westermeier AS, Masselter T, Speck T (2016) Fastest predators in the plant kingdom: functional morphology and biomechanics of suction traps found in the largest genus of carnivorous plants. AoB Plants 8:plv140

Rachmilevitz T, Fahn A (1975) The floral nectary of Tropaeolum majus L. - the nature of the secretory cells and the manner of nectar secretion. Ann Bot 39(4):721-728

Reut MS (1993) Trap structure of the carnivorous plant Genlisea (Lentibulariaceae). Bot Hely 103:101-111

Reynolds ES (1963) The use of lead citrate at high $\mathrm{pH}$ as an electron opaque stain for electron microscopy. J Cell Biol 17(1):208-212

Roccia A, Gluch O, Lampard S, Robinson A, Fleischmann A, McPherson S, Legendre L, Partrat E, Temple P (2016) Pinguicula of the temperate north. Redfern, Dorset pp 350

Rocha JF, Machado RS (2009) Anatomy, ultrstructure and secretion of Hibiscus pernambucensis Arruda (Malvaceae) extrafloral nectary. Br J Bot 32(3):489-498

Schäferhoff B, Fleischmann A, Fischer E, Albach DC, Borsch T, Heubl G, Müller KF (2010) Towards resolving Lamiales relationships: insights from rapidly evolving chloroplast sequences. BMC Evol Biol 10(1):352
Schnell DE (1976) Carnivorous plants of the United States and Canada. John F. Blair, Winston Salem

Silva SR, Gibson R, Adamec L, Domínguez Y, Miranda VFO (2018) Molecular phylogeny of bladderworts: a wide approach of Utricularia (Lentibulariaceae) species relationships based on six plastidial and nuclear DNA sequences. Mol Phylogenet Evol 118: 244-264

Stpiczyńska M (2003) Nectar resorption in the spur of Platanthera chlorantha Custer (Rchb.) Orchidaceae-structural and microautoradiographic study. Plant Syst Evol 238(1-4):119-126

Taylor P (1989) The genus Utricularia - a taxonomic monograph. Kew Bull Addit Ser 14:1-724

Tresmondi F, Canaveze Y, Guimarães E, Machado SR (2017) Colleters in Rubiaceae from forest and savanna: the link between secretion and environment. Sci Nat 104(3-4):17

Villegas SG, Alcalá RE (2018) Reproductive ecology of the carnivorous plant Pinguicula moranensis (Lentibulariaceae). Plant Biol 20(2): 205-212

Weryszko-Chmielewska E, Chwil M (2016) Flowering biology and structure of floral nectaries in Galanthus nivalis L. Acta Soc Bot Pol 85: $1-20$

Wist JT, Davis AR (2006) Floral nectar production and nectary anatomy and ultrastructure of Echinacea purpurea (Asteraceae). Ann Bot 97(2):177-193

Zamora R (1990) The feeding ecology of a carnivorous plant (Pinguicula nevadense): prey analysis and capture constraints. Oecologica 84(3): 376-379

Zamora R (1999) Conditional outcomes of interactions: the pollinatorprey conflict of an insectivorous plant. Ecology 80(3):786-795

Zamudio S (2001) Revisión de la sección orcheosanthus, del género Pinguicula (Lentibulariaceae). $\mathrm{PhD}$ thesis, National University of Mexico http://www.pinguicula.org/pages/pages_principales/ content.html. Accessed 24 July 2019

Publisher's note Springer Nature remains neutral with regard to jurisdictional claims in published maps and institutional affiliations. 